\title{
FOXP3, IL-10, and TGF- $\beta$ Genes Expression in Children with IgE-Dependent Food Allergy
}

\author{
Aneta Krogulska • Maciej Borowiec • \\ Ewa Polakowska • Jarosław Dynowski • \\ Wojciech Młynarski • Krystyna Wasowska-Królikowska
}

Received: 27 September 2010 / Accepted: 3 November 2010 /Published online: 24 November 2010

(C) The Author(s) 2010. This article is published with open access at Springerlink.com

\begin{abstract}
Background Regulatory $\mathrm{T}$ cells (Tregs) have an essential role in tolerance and immune regulation. However, few and controversial data have been published to date on the role and number of these cells in food allergic children. The forkhead/winged-helix transcription factor box protein 3 (FOXP3) is considered the most reliable marker for Tregs.

Objective This study aims to investigate the FOXP3, interleukin (IL)-10, and transforming growth factor (TGF$\beta)$ genes expression in children with IgE-dependent food allergy.

Material and Methods The study group consisted of 54 children with IgE-dependent food allergy (FA) and a control group of 26 non-atopic healthy children. The diagnosis of FA was established using questionnaires, clinical criteria, skin prick tests, serum sIgE antibodies (UniCAP 100 Pharmacia Upjohn), and a double-blind placebo control food challenge. In order to assess gene expression, the isolation of nucleated cells was performed using Histopaque-1077 (Sigma-Aldrich, Germany). The
\end{abstract}

Source of support: This study is supported by the grant no. 502-11750 from the Medical University of Lodz.

A. Krogulska $(\bowtie) \cdot J$. Dynowski $\cdot$ K. Wasowska-Królikowska Department of Pediatric Allergology,

Gastroenterology and Nutrition, Medical University of Lodz, Sporna 36/50,

91-738, Lodz, Poland

e-mail: anetkrog@poczta.onet.pl

M. Borowiec $\cdot$ E. Polakowska $\cdot$ W. Młynarski

Laboratory of Immunopathology and Genetics,

Department of Pediatrics, Oncology, Hematology and Diabetes,

Medical University of Lodz,

Lodz, Poland concentration of RNA obtained was measured using a super-sensitive NanoDrop ND1000 spectrophotometer (Thermo Scientific, USA). A reverse transcription reaction was performed using a commercially available set of High Capacity cDNA Archive Kit (Applied Biosystems, USA). Analysis have been carried out in the genetic analyzer 7900HT Real-Time PCR (Applied Biosystems, USA).

Results The average level of the FOXP3 gene expression in the studied group was $2.19 \pm 1.16$ and in the control group $2.88 \pm 1.66(p=0.03)$. The average level of IL10 mRNA expression in the study group was $13.6 \pm 1.07$ and was significantly lower than corresponding values in the control group $14.3 \pm 1.1 \quad(p=0.01)$. There were no significant differences in the average level of the TGF- $\beta$ mRNA expression in the study group (3.4 \pm 0.4$)$ and controls $(3.5 \pm$ $0.3 ; p>0.05)$. The FOXP3 gene expression was the highest in children who acquired tolerance to food $(3.54 \pm 0.75)$, lower in heated allergen-tolerant children $(2.43 \pm 0.81)$, and the lowest in heated allergen-reactive children $(1.18 \pm 0.5$; $p=0.001$ control vs heated allergen reactive; $p=0.005$ heated allergen tolerant vs heated allergen reactive; $p=$ 0.001 outgrown vs heated allergen reactive). The significant tendency toward lower total $\mathrm{IgE}$ levels with a higher FOXP3 mRNA expression was detected $(n=54$; Pearson $r=-0.4393 ; p=0.001$ ).

Conclusions Children with FA showed statistically significant lower level of the FOXP3 and IL10 gene expression than healthy children. Children acquiring tolerance to the food show significantly higher levels of the FOXP3 gene expression than children with active FA. The correlation between the level of FOXP3 and total IgE was detected.

Keywords FOXP3 $\cdot$ Treg cells $\cdot$ IL-10 · TG- $\beta$ children · food allergy 


\begin{tabular}{|c|c|}
\hline \multicolumn{2}{|c|}{ Abbreviations } \\
\hline FA & Food allergy \\
\hline CMA & Cow milk allergy \\
\hline Tregs & Regulatory $\mathrm{T}$ cells \\
\hline FOXP3 & $\begin{array}{l}\text { Forkhead/winged-helix transcription factor } \\
\text { box protein } 3\end{array}$ \\
\hline TGF- $\beta$ & Transforming growth factor \\
\hline $\mathrm{APCs}$ & Antigen-presenting cells \\
\hline DBPCFCs & Double-blind placebo control food challenge \\
\hline $\mathrm{AD}$ & Atopic dermatitis \\
\hline $\mathrm{AR}$ & Allergic rhinitis \\
\hline EAACI & $\begin{array}{l}\text { European Academy of Allergy and Clinical } \\
\text { Immunology }\end{array}$ \\
\hline PBMC & Peripheral blood mononuclear cell \\
\hline PCR & Polymerase chain reaction \\
\hline
\end{tabular}

\section{Introduction}

A failure in the establishment and maintenance of oral tolerance in infancy may result in food allergy (FA). The recent reports have supported the hypothesized role for regulatory $\mathrm{T}$ cells (Tregs) in the development of normal tolerance or the spontaneous resolution of milk allergy [13]. Indirect evidence exists to suggest that the development of FA may be controlled by CD4+CD25+ Treg cells [4] Generally, several Tregs have been found to be important for oral tolerance: Th3 cells, a population of $\mathrm{CD} 4+$ cells that secrete transforming growth factor (TGF- $\beta$ ); T regulatory type $1(\operatorname{Tr} 1)$ cells, cells that secrete IL-10; CD4+CD25 + regulatory $\mathrm{T}$ cells, cells that express the transcription factor forkhead/winged-helix transcription factor box protein 3 (FOXP3); CD8+ suppressor T cells; and gamma-delta $\mathrm{T}$ cells. The best characterized Tregs are $\mathrm{CD} 4+\mathrm{T}$ cells that constitutively express high levels of surface CD25 (the IL-2 receptor chain: CD25hi T cells). Unlike CD4+ Th cells, these CD25hi cells do not proliferate or produce cytokines when stimulated with antigen but actively suppress proliferation and cytokine production from effector $\mathrm{T}$ cells involved in mediating inflammation $[5,6]$. Current evidence suggests that CD4+CD25+ Treg cells employ several mechanisms to suppress immune responses: via direct cell contact, indirectly by reducing the antigen-presenting capacity of antigen-presenting cells (APCs) [7] or by suppressive cytokines $[8,9]$. Candidate molecules responsible for the immunosuppressive function of Tregs include inhibitory cytokines IL-10 and TGF- $\beta$. TGF- $\beta$ has been demonstrated to play a key role in the regulation of the immune response, mainly by inhibiting proliferation of lymphocytes $\mathrm{T}$, lymphocytes $\mathrm{B}$, NK cells, and expression of major histocompatibility complex (MHC) class II molecules on APCs. In turn, IL-10 inhibits pro- inflammatory cytokine production by effector lymphocytes, monocytes, and macrophages and also reduces the ability of APCs to express MHC class II molecules. Several studies indicate the role of TGF- $\beta$ and IL-10 in the pathogenesis of allergic diseases [1, 3, 10-13]; however, recent data are conflicting [14].

The CD4+CD25+ Tregs owe their suppressive phenotype in a large part to the expression of high levels of FOXP3 $[7,15,16]$. The FOXP3 is considered the most reliable marker for Tregs performing a major role in the formation and functioning of lymphocytes T CD4+CD25+ [16-19]. The level of FOXP3 expression has been shown to correlate with suppressive activity $[16,19]$. The expression of FOXP3 primarily concerns nTreg, but it is also found to a lesser extent and temporarily in effector T cells. Tr1 cells show no FOXP3 expression. Furthermore, FOXP3 overexpression increases the number of Tregs [20].

Consequences of deficiency or dysfunction of Treg cells CD4+CD25+ in the development of allergic diseases are the subject of many studies [21-25]; however, studies assessing the importance of Tregs in children with allergies, especially with FA, are rare [26-29]. Previous studies have tried to find the answers to the main questions: whether there is any relationship between Tregs during prenatal life and the risk of FA, as well as FA occurrence and FA outgrowing, and whether the effects of Tregs depend on their number or function [26-28, 30-33].

Based on these considerations, the aim of the present study was to determine the (1) gene FOXP3 expression (representing Tregs) in children with IgE-dependent cow's milk or egg's allergy in comparison to healthy non-atopic children, (2) IL-10 and TGF- $\beta$ mRNA expression in the same groups, (3) relationship between these immunologic indicators and the course of food allergy, and (4) probable correlations between them. This is the first study which evaluates the FOXP3, IL-10, and TGF- $\beta$ gene expression in children with IgE-dependent FA in Polish children.

\section{Materials and Methods}

\section{Subjects}

Subjects with IgE-dependent FA were recruited from the Department of Pediatric Allergology, Gastroenterology and Nutrition of the Medical University of Lodz and the Outpatient Allergology Clinics. The study was approved by the institutional ethics committee, and informed consent was obtained before enrollment.

Between January 2004 and December 2008, we enrolled 679 children with a suspicion of cow milk or egg allergy. A lack of data or cooperation resulted in exclusion of 61 cases. Skin prick tests and/or specific IgE revealed 
sensitization to food allergens in 193 children. In 143 children, elimination diet caused improvement. Doubleblind placebo control food challenge (DBPCFCs) were planned for 135 children. The DBPCFC was not carried out in five of children because of a well-documented history of reaction and reported anaphylactic reactions. Seven children were lost, so 143 food challenges were carried out in 131 children. The food allergy was confirmed in 59 children. All together, food allergy was diagnosed in 64 children. A lack of data or cooperation resulted in exclusion of ten cases. Therefore, a group of 54 children with IgEdependent cow milk or egg allergy was subjected to further investigations. In the study group, ten children had concomitant atopic dermatitis (AD); six $\mathrm{AD}$ and allergic rhinitis (AR); nine $\mathrm{AD}$ and asthma; eight $\mathrm{AD}$, asthma, and $\mathrm{AR}$; one asthma; $11 \mathrm{AR}$; and nine digestive tract complaints - seven due to immediate type of food allergy, i.e., nausea, vomiting, diarrhea, abdominal pain, and two due to eosinophilic esophagitis. The control group comprised 26 non-atopic children without FA. Characteristics of the study and control groups were shown in Table I.

\section{Methods}

The diagnosis of FA was established using questionnaires, clinical criteria, skin prick tests to specific food allergens, serum sIgE antibodies directed against the food allergens, and the DBPCFC. Exclusion of FA was confirmed by questionnaires, skin prick tests to specific food allergens, and serum sIgE antibodies directed against the food

Table I Patients' characteristics

\begin{tabular}{lll}
\hline & Study group & Control group \\
\hline Total subjects & 54 & 26 \\
Age (years), mean \pm SD & $6.3 \pm 5.2$ & $6.8 \pm 5.6$ \\
Male sex, $n$ (\%) & $32(57)$ & $13(50)$ \\
Family history of atopy, $n(\%)$ & $45(83.3)$ & $2(7.7)$ \\
Total IgE (IU/ml) & & \\
Mean \pm SD & $596.9 \pm 565.4$ & $57.1 \pm 32.4$ \\
Range & $39-2,000$ & \\
sIgE IU/ml & & \\
Mean \pm SD & $14.8 \pm 24.2$ & - \\
Range & $1.2-100$ & \\
Cow milk allergy subjects, $n(\%)$ & $28(51.8)$ & - \\
Heated reactive & $10(35.7)$ & \\
Heated tolerant & $10(35.7)$ & \\
Outgrown & $8(28.6)$ & \\
Egg allergy subjects, $n(\%)$ & $26(48.2)$ & - \\
Heated reactive & $12(46.2)$ & \\
Heated tolerant & $9(34.6)$ \\
Outgrown & $5(19.2)$
\end{tabular}

allergens and food challenge. The allergens responsible for positive results in the food challenge were milk in 27 children and egg in 24 children. In three children, one allergic to milk and two to eggs, the DBPCFC was not carried out because of a well-documented history of reaction and reported anaphylactic reactions. Blood samples for evaluation of FOXP3, IL-10, and TGF- $\beta$ genes expression were collected from patients who had been in a stable condition for $\geq 6$ weeks, out of season in the case of concomitant seasonal allergy, and at least 2 weeks after entering elimination diet.

\section{Skin Prick Test}

Standardization of the method was in line with the position papers of the European Academy of Allergy and Clinical Immunology (EAACI) [34]. Standard allergen extracts were provided by Allergopharma (Reinbek, Germany). Positive control was $10 \mathrm{mg} / \mathrm{ml}$ histamine (Allergopharma). As a negative control, $50 \%$ glycerosaline solution was used. Reactions to each allergen were measured $15 \mathrm{~min}$ after the pricks. The food allergens included milk and egg; cereals: wheat flour and rye flour; fish, soy, cocoa, sesame, peanut, and hazelnut; fruits: apple, peach, and orange; and vegetables: celery, carrot, potato, and tomato. Skin prick test positivity was defined as a wheal of at least $3 \mathrm{~mm}$ being larger than the negative control. Data were excluded if the saline control was $\geq 3 \mathrm{~mm}$, the histamine control was $<3 \mathrm{~mm}$, or if the difference of histamine minus saline was $<3 \mathrm{~mm}$.

\section{Serum Specific IgE Antibodies}

Specific IgE for milk, egg, wheat flour and rye flour, fish, shrimp, soy, cocoa, sesame, peanut, and hazelnut; fruit: apple, peach, and orange; and vegetables: celery, carrot, potato, and tomato were measured using the UniCAP 100 Pharmacia Upjohn (Pharmacia Diagnostics AB, Uppsala, Sweden).

\section{Food Challenge}

The oral challenge tests were performed using the DBPCFC method. The trials were carried out in hospitalized patients according to EAACI recommendations, after a minimum 2week eliminating diet [35]. Systemic corticosteroids were contraindicated, and systemic antihistamines were withdrawn according to their half-life. The use of topical corticosteroids for the airways was no reason to discontinue testing; topical corticosteroids for skin complaints were tapered to the minimum dose and kept constant throughout the challenge procedure. The $\beta 2$-adrenergic agonists and theophylline were avoided for $48 \mathrm{~h}$ prior to the challenge. 
In the provocative procedures, the native foods were used: milk and egg. The patients were observed for at least $4 \mathrm{~h}$ after the completion of the final challenge. The food challenge results were scored as negative, mild to moderate, or severe using a clinical reference table adapted from Sampson and Benhamou et al. [36, 37]. The oral challenge tests were performed in two time points: at the onset and the end of the study. At the end of the study, all children underwent a standardized food challenge on two sequenced days: the first day with extensively heated products and the next day with the unheated products. The patients were characterized by a heated allergen product such as heated allergen reactive $(n=22)$ or heated allergen tolerant $(n=32)$ and by an unheated allergen product such as unheated allergen reactive (heated allergen tolerant; $n=19$ ) or as allergen tolerant (i.e., outgrown; $n=13$ ).

\section{Cell Isolation}

Isolation of nucleated cells from peripheral blood collected for the patient Vacutiner vacuum system was performed with the addition of an anti-coagulant EDTA. The isolation was carried out in a strictly conforming to study density gradient according to the standard protocol provided with the isolation system. The isolation was carried out using Histopaque ${ }^{\circledR}-1077$ (Sigma-Aldrich, Germany) with a gradient of density 1.077. RNA was isolated from these nucleated cells in peripheral blood of patients using the modified method of Chomczynski. TRI reagent (Invitrogen, Germany) was used for proper isolation, and the process was conducted according to the standard protocol. The concentration of RNA obtained was measured using a super-sensitive NanoDrop ND1000 spectrophotometer (Thermo Scientific, USA).

\section{RT-PCR Experiments}

Reverse transcription reaction was performed using a commercially available set of High Capacity cDNA Archive Kit (Applied Biosystems, USA). cDNA was prepared from $1 \mu \mathrm{g}$ of mRNA, with random hexamer primers, according to the manufacturer's instructions$10 \min 25^{\circ} \mathrm{C}, 2 \mathrm{~h} 37^{\circ} \mathrm{C}$, and $4^{\circ} \mathrm{C}$ thereafter on a PCR thermocycler Gene (Applied Biosystems, USA). The resulting cDNA was diluted to a final concentration of $5 \mathrm{ng} / \mu \mathrm{l}$ and constituted a matrix in further experiments.

\section{Expression Experiments}

The analysis of FOXP3 gene expression was constructed using a human commercial available assay Hs01085830_m1 (Applied Biosystems, USA), IL-10 assay Hs99999035_m1,
Hs00610319_m1 TGF- $\beta$ assay, and human beta-actin (Applied Biosystems, USA), which were controlled by an internal reaction while allowing a reliable determination of absolute values and the expression of FOXP3 genes, IL-10, and TGF- $\beta$. The analysis was carried out in the genetic analyzer 7900HT Real-Time PCR (Applied Biosystems, USA). Comparative analyses of each of these genes in individual patients were performed using specialized computer programs SDS2.3 and RQ 2.1 (Applied Biosystems, USA). All amplifications were carried out at least in duplicates. The mRNA expression levels of each gene were calculated by using the $2^{-\Delta \Delta C^{\mathrm{T}}}$ (comparative threshold cycle, or $C_{\mathrm{T}}$ ) method, as detailed by the manufacturer (Technical Bulletin 2; Applied Biosystems).

\section{Statistical Analysis}

For calculation of absolute values, data were logarithmically transformed to assure normality of distribution. The mean values of measurable features (arithmetic means), variable ranges (min-max), and their internal differentiation with standard deviations were calculated. In order to determine the significance of differences between mean values of the parameters in different groups of children, the analysis of the variance test of $F$-Snedecor was used with post hoc analysis performed with honestly significant difference Tukey's test. The Pearson's $r$ rank correlation coefficients were used to evaluate relationships between continuous variables and the Student's test to verify the significance of the correlation coefficient. The value of $p \leq 0.05$ was considered statistically significant. The program STATISTICA 8.0 (StatSoft, Tulsa, OK, USA) was used for calculations.

\section{Results}

Among the study group, there were 28 cow's milk allergy children and 26 egg's allergy children. Clinical signs observed after food challenges in the study group are shown in Table II. The average level of FOXP3 gene expression in the studied group was $2.18 \pm 1.16$ and in the control group $2.88 \pm 1.66(p=0.03)$. In turn, the average level of IL-10 mRNA expression in the study group was $13.6 \pm 1.07$ and was significantly lower than the corresponding values in the control group $14.3 \pm 1.1$ ( $p=$ $0.01)$. There were no significant differences in the average level of the TGF- $\beta$ mRNA expression in the study group (3.4 \pm 0.4$)$ and controls $(3.5 \pm 0.3 ; p>0.05$; Fig. 1).

In 19 children with a mild anaphylactic reaction after oral food challenge, the average level of FOXP3 gene expression was $2.26 \pm 1.16$; in 25 children with a moderate 
Table II The course of food challenges in the study group

\begin{tabular}{|c|c|c|c|c|c|c|c|}
\hline & \multicolumn{3}{|c|}{ One organ system involved $(n=37)$} & \multicolumn{3}{|c|}{$\geq 2$ organ system involved $(n=17)$} & \multirow{2}{*}{$\begin{array}{l}\text { Total, } \\
n(\%)\end{array}$} \\
\hline & Skin, $n$ & Gastrointestinal, $n$ & Respiratory, $n$ & $\begin{array}{l}\text { Skin }+ \\
\text { gastrointestinal, } n\end{array}$ & $\begin{array}{l}\text { Skin }+ \text { gastrointestinal }+ \\
\text { respiratory, } n\end{array}$ & Skin + respiratory, $n$ & \\
\hline Milk & 14 & 2 & 4 & 3 & 1 & 4 & $28(51.8)$ \\
\hline Egg & 8 & 6 & 3 & 3 & - & 6 & $26(48.2)$ \\
\hline Total, $n(\%)$ & $22(40.7)$ & $8(14.8)$ & $7(12.9)$ & $6(11.2)$ & $1(1.9)$ & $10(18.5)$ & $54(100)$ \\
\hline
\end{tabular}

response, it was $2.4 \pm 1.2$; and in ten children with a severe reaction, it was $1.5 \pm 0.8(p=0.05$; Table III).

In order to assess FOXP3 gene expression, depending on the clinical course of allergy and the development of tolerance, three groups of children were selected: (1) children who did not tolerate the food allergen in any form, i.e., heated allergen reactive $(n=$ 22); (2) children with heated allergen tolerance, i.e., children with a milder course of food allergy $(n=19)$; and (3) children who acquired tolerance to food $(n=13)$. A statistically significant difference in the FOXP3 gene expression among heated allergen-reactive children $(n=$ $22 ; 1.18 \pm 0.5)$ and the other food allergic children $(n=32$; $3.08 \pm 0.87)$ was observed $(p=0.001)$. The FOXP3 gene expression was the highest in children who acquired tolerance to food $(3.54 \pm 0.75)$, lower in heated tolerant children $(2.4 \pm 0.8)$, and the lowest in heated reactive children $(1.18 \pm 0.5) \quad(p=0.001$ control vs heated allergen reactive; $p=0.005$ heated allergen tolerant vs heated allergen reactive; $p=0.001$ outgrown vs heated allergen reactive; Fig. 2).

There was no statistically significant correlation between FOXP3, IL-10, or TGF- $\beta$ expression and age $(r=-0.0605$; $r=0.2478 ; r=-0.1651 ; p>0.05)$, although there was a

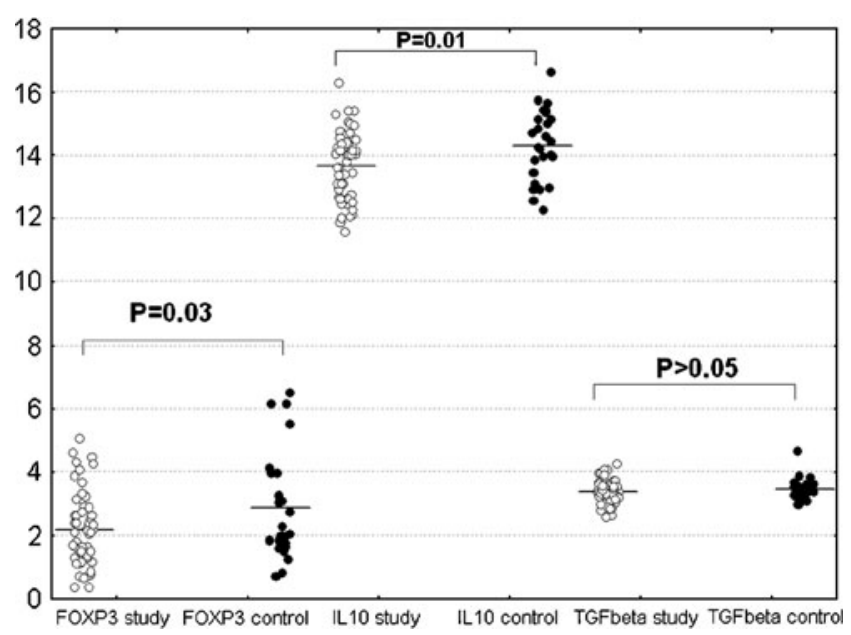

Fig. 1 FOXP3, IL10, and TGF- $\beta$ expression in control and study group significant negative correlation between the average level of expression of IL-10 and age in children up to 3 years of life, which was not found in older children $(r=-0.3876$; $p=$ 0.04). The significant tendency toward lower total $\mathrm{IgE}$ (tIgE) levels with higher FOXP3 mRNA expression was detected $(r=-0.4393 ; p=0.001 ;$ Fig. 3a). There was no correlation between IL-10 or TGF- $\beta$ expression and tgE levels $(r=0.0185 ; r=0.0193 ; p>0.05)$. Likewise, there was no statistically significant correlation between FOXP3, IL10 , or TGF- $\beta$ expression and sIgE level $(r=-0.0285 ; r=$ $0.0449 ; r=0.0873 ; p>0.05)$.

A statistically significant correlation between FOXP3 expression and tIgE levels depending on reaction grade during food challenge was also demonstrated (moderate reaction $r=-0.4178 ; p=0.03$; severe reaction $r=-0.6602$; $p=0.03$; Fig. 3b).

On the other hand, insignificant differences between the average level of IL-10 and TGF- $\beta$ expression, depending on the type of response during food challenge (Table III), were beyond stating a negative relationship between the average level of the expression of TGF- $\beta$ and the age in children with mild reactions after the oral challenge test with food ( $r=-0.4623 ; p=0.04)$.

There were no significant differences between the average level of expression of IL-10 and TGF- $\beta$ depending on the course of FA in children (Fig. 2). However, the correlation between the average level of IL10 expression and age in children with mild food allergy (heated allergen tolerant) was detected $(r=0.4994$; $p=0.03$ ).

There was no statistically significant correlation between FOXP3 expression and IL-10 mRNA expression $(r=-0.0315 ; p>0.05)$. The same lack of correlation between FOXP3 mRNA expression and TGF- $\beta$ expression was detected $(r=-0.1527 ; p>0.05)$, as well as between TGF- $\beta$ expression and IL-10 expression $(r=$ $-0.1201 ; p>0.05)$.

Ten children in the study group used inhaled corticosteroids (ICS). Of these, six children had a severe reaction in the oral challenge. The average level of FOXP3 in ten children taking ICS was 1.7, while in other children was 2.8 . 
Table III FOXP3, IL-10, and TGF- $\beta$ gene expression in the relationship to the grade of reaction in the course of food challenge

\begin{tabular}{llccc}
\hline & Reaction grade in the course of food challenge & FOXP3 mean \pm SD & IL-10 mean \pm SD & TGF- $\beta$ mean \pm SD \\
\hline \multirow{2}{*}{ Study group } & Mild & $2.26 \pm 1.16$ & $13.55 \pm 1.19$ & $3.39 \pm 0.38$ \\
& Moderate & $2.4 \pm 1.2$ & $13.87 \pm 0.98$ & $3.38 \pm 0.38$ \\
& Severe & $1.5 \pm 0.82$ & $13.35 \pm 0.95$ & $3.38 \pm 0.27$ \\
Control group & & $2.88 \pm 1.66$ & $14.3 \pm 1.11$ & $3.46 \pm 0.32$ \\
\hline
\end{tabular}

$p=0.05$

\section{Discussion}

Our study shows that the average levels of FOXP3 and IL10 gene expression were significantly lower in children with IgE-dependent FA than in the control group. There were no differences of TGF- $\beta$ expression between groups. These results may suggest diminished number or defect of Tregs and impaired function of IL-10 in FA children.

It was confirmed that the amount of FOXP3 mRNA expression correlated directly with the percentage of Treg cells in peripheral blood mononuclear cells (PBMCs) determined by flow cytometry [38]. More than $95 \%$ of normal human peripheral blood CD3 $+\mathrm{T}$ cells that express FOXP3 are found in the CD4+ population. Thus, we utilized FOXP3 mRNA as a surrogate marker for relative Treg numbers.

Most findings of Tregs activity in allergic disease come from studies of immunotherapy [39] rather than spontaneous tolerance, and the most convincing data suggest a role for the IL-10 secreting, so-called Tr1 [6]. Based on the mouse model of FA, it has been shown that TGF- $\beta$ and FOXP3 may be the aims of further studies on immunotherapy in FA [40]. Mori et al. demonstrate that CD4+CD25+Foxp3+ T

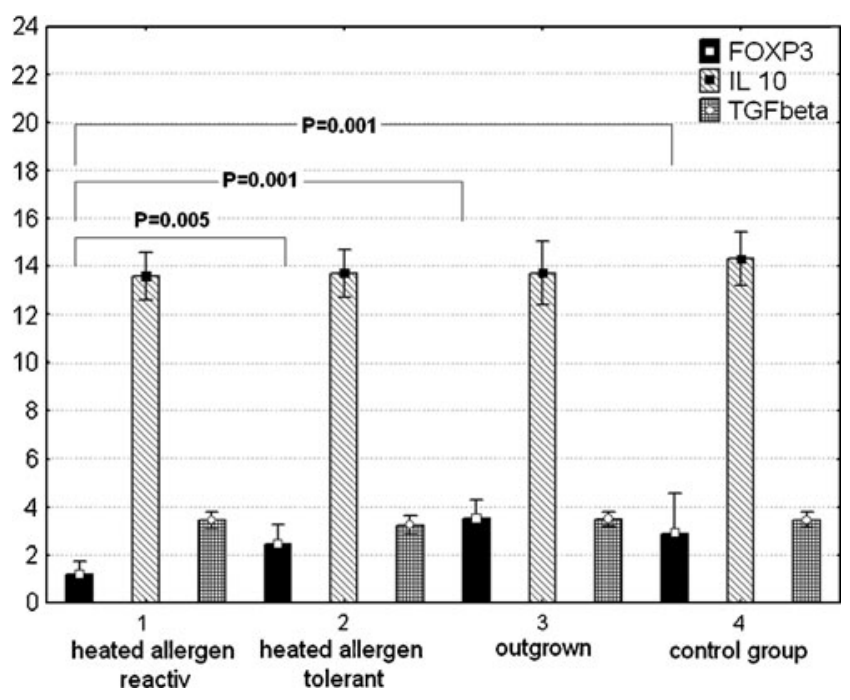

Fig. 2 FOXP3, IL10, and TGF- $\beta$ expression in control and study group: 1 heated allergen reactive, 2 heated allergen tolerant, 3 outgrown, and 4 control cells have no significance in oral desensitization in children with FA but play an important role in achieving natural tolerance in children with CMA [41]. Our study seems to partly confirm this finding.

In general, the knowledge on the role and suppressive effect of CD4+CD25+ Tregs in atopic subjects is still limited and somewhat contradictory. Several studies suggest that the number or function of Tregs is impaired or altered in patients with allergies compared with healthy individuals $[4,6,20-22,24-26,28,30,42-47$, $49,50]$. Our results are consistent with these independent lines of evidence. However, there are many other results, which have shown the opposite [21, 33, 46, 47]. It seems that the diversity of results in terms of the number or function of Tregs in the pathogenesis of allergic diseases may be related to difficulties in proper identification of Tregs using conventional cell markers, as well as to different allergic diseases, disease status, patients' age, differential severity, differential environmental influences, or differential methods.

Data concerning the role of Treg in the pathogenesis of pediatric allergic disease are rare. The study of Hinz et al. indicates that reduced maternal Treg numbers during pregnancy might influence the allergy risk of the child [32]. Haddeland et al. found that neonates at high atopic risk generated reduced numbers of CD4+CD25+ cells with diminished capacity [31].

The role of CD4+CD25+ Tregs in FA is not well established. The reported frequency of Tregs in peripheral blood from patients with FA is inconsistent. Summary of the literature is demonstrated in Table IV [26-30, 42]. Rare studies evaluate the role of Tregs in FA in parallel with the expression of FOXP3 mRNA (the method used in our study) [27, 29, 30, 42]. Differences in comparison with our study may stem from different samples, different patient age, and different methods.

The relationship between Tregs still in uterus and risk of FA at the first year of life was the aim of the study of Smith et al. [30]. This study demonstrated diminished function of CD4+CD25+ Tregs in newborns at risk of egg allergy development. However, it was suggested that although FOXP3 is a useful marker of neonatal Tregs, it does not predict function of these cells. In this light, we do not know 
a

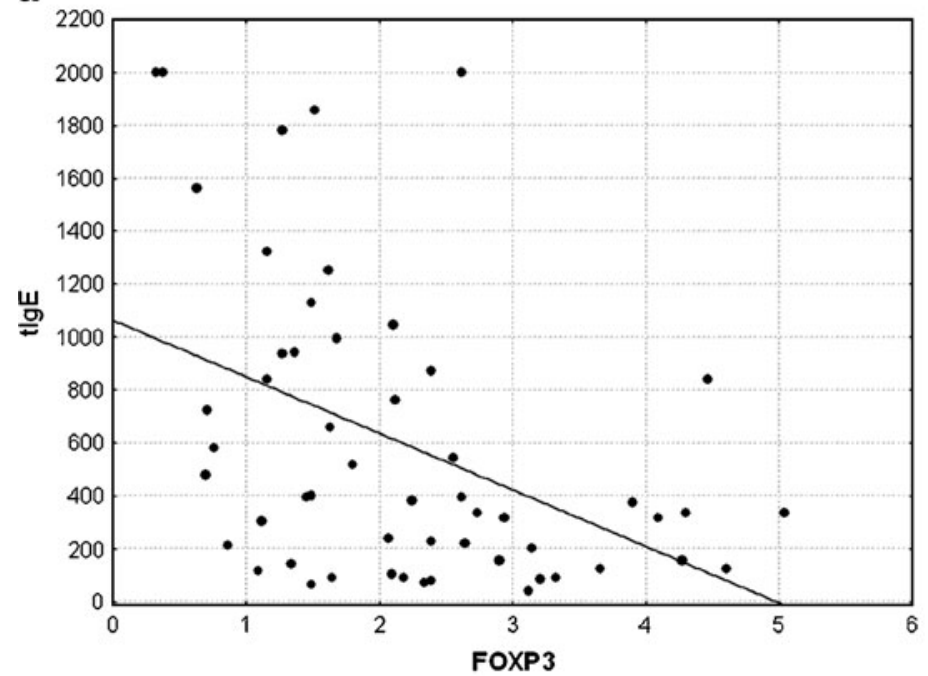

b
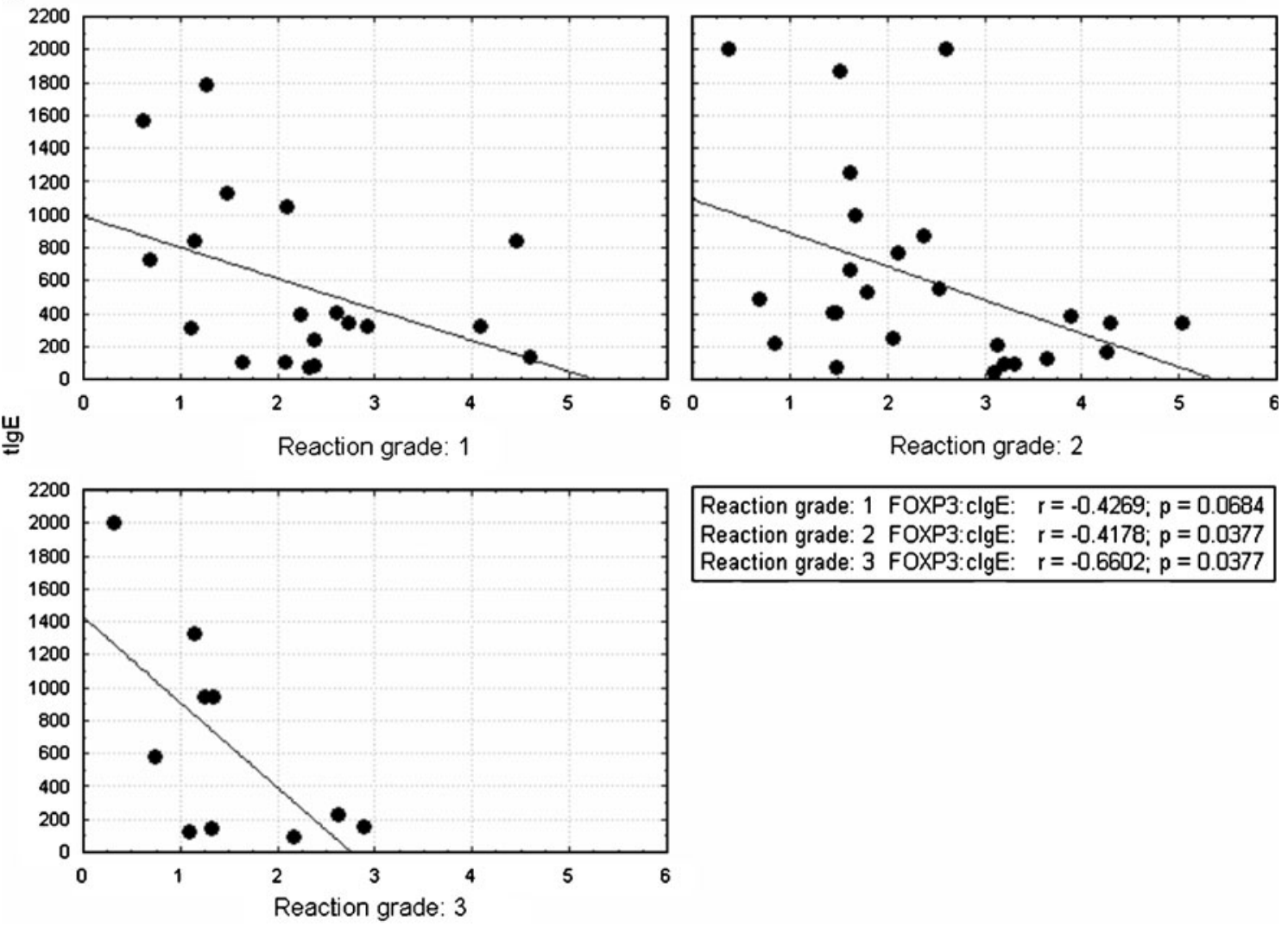

Reaction grade: 1 FOXP3: clgE: $r=-0.4269 ; p=0.0684$

Reaction grade: 2 FOXP3: clgE: $r=-0.4178 ; p=0.0377$

Reaction grade: 3 FOXP3: clgE: $r=-0.6602 ; p=0.0377$

Fig. 3 a. FOXP3 expression in correlation with tIgE in study group. b. FOXP3 expression in correlation with tIgE and reaction grade during food challenge

whether the decreased FOXP3 expression in our study can be explained by the function defect or drop in the frequency of Tregs.

Furthermore, increased levels of CD4+CD25+ Tregs have been reported to be associated with acquired tolerance to cow's milk [26]. Karlsson et al. found that PBMCs from children who outgrown CMA had higher percentages of total $\mathrm{CD} 4+\mathrm{CD} 25+$ and were less proliferative to milk allergen than their counterparts who still had allergy. A recent study by Shreffler et al. reported a difference in antigen-specific but not polyclonal Tregs in children with CMA [28]. Shreffler et al. showed that children with HM tolerance more quickly outgrow of allergies than children with allergies to $\mathrm{HM}$ and have simultaneously a higher 
Table IV Summary of literatures concerning the role of Treg in food allergy

\begin{tabular}{|c|c|c|c|c|c|c|c|c|}
\hline Study & Age & $\begin{array}{l}\text { Patient } \\
\text { number }\end{array}$ & Diseases & $\begin{array}{l}\text { Phenotype } \\
\text { of Treg } \\
\text { measured by } \\
\text { flow cytometry }\end{array}$ & $\begin{array}{l}\text { Number } \\
\text { of Treg }\end{array}$ & $\begin{array}{l}\text { Function } \\
\text { of Treg }\end{array}$ & $\begin{array}{l}\text { Expression } \\
\text { FOXP3 } \\
\text { mRNA } \\
\text { (RT-PCR) }\end{array}$ & Conclusions \\
\hline $\begin{array}{l}\text { Smith } \\
\text { et al. [30] }\end{array}$ & $\begin{array}{l}0-12 \\
\text { months }\end{array}$ & $\begin{array}{l}15 \\
\text { children }\end{array}$ & Egg allergy & $\begin{array}{l}\mathrm{CD} 4(+) \mathrm{CD} 25(+) \\
\mathrm{CD} 127(\mathrm{lo} /-) \\
\text { Treg cells }\end{array}$ & $\begin{array}{l}\equiv \text { in } \mathrm{CB}^{\mathrm{a}} \\
\text { although a } \downarrow \\
\text { proportion in FA }\end{array}$ & $\downarrow$ & $\equiv$ & $\begin{array}{l}\text { This study } \\
\text { provides evidence } \\
\text { of perinatal differences } \\
\text { in Treg cell } \\
\text { function in neonates } \\
\text { who progress to } \\
\text { allergic disease }\end{array}$ \\
\hline $\begin{array}{l}\text { Karlsson } \\
\text { et al. [26] }\end{array}$ & $\begin{array}{l}\text { 6-56 } \\
\text { months }\end{array}$ & 21 children & $\begin{array}{l}\text { CMA } \\
8 \text { persistent } \\
\text { allergy } \\
13 \text { tolerant }\end{array}$ & $\begin{array}{l}\mathrm{CD} 4+\mathrm{CD} 25+ \\
\mathrm{T} \text { cells }\end{array}$ & $\begin{array}{l}\downarrow \text { in } \mathrm{PB}^{\mathrm{a}} \\
\text { in persistent } \\
\mathrm{CMA} \\
\uparrow \text { in } \mathrm{PB}^{\mathrm{a}} \\
\text { in tolerant }\end{array}$ & $\begin{array}{l}\downarrow \text { in persistent } \\
\text { CMA }\end{array}$ & n.a. & $\begin{array}{l}\text { Children who outgrew } \\
\text { their allergy had } \\
\uparrow \text { frequencies of } \\
\text { circulating CD4+CD25+ } \\
T \text { cells }{ }^{\mathrm{c}} \text { and decreased } \\
\text { in vitro proliferative } \\
\text { responses to bovine } \\
\beta \text {-lactoglobulin } \\
\text { in PBMCs }\end{array}$ \\
\hline $\begin{array}{l}\text { Savilahti } \\
\text { et al. [27] }\end{array}$ & $\begin{array}{c}5.4-12.3 \\
\text { years }\end{array}$ & $\begin{array}{l}57 \\
\text { children }\end{array}$ & $\begin{array}{l}\text { CMA } \\
16 \text { active CMA } \\
20 \text { tolerant }\end{array}$ & $\begin{array}{l}\text { CD4+CD25high } \\
\text { CD127 low } \\
\text { T cells }\end{array}$ & $\equiv$ in $\mathrm{PB}^{\mathrm{a}}$ & n.a. & $\begin{array}{l}\uparrow \text { highest in } \\
\text { children with } \\
\text { persisting CMA }\end{array}$ & $\begin{array}{l}\text { T regulatory cell-related } \\
\text { genes reflect the } \\
\text { clinical activity of } \\
\text { CMA. Tolerance } \\
\text { is not characterized } \\
\text { by activation of } \\
\text { circulating T } \\
\text { regulatory cells }\end{array}$ \\
\hline $\begin{array}{l}\text { Shreffler } \\
\text { et al. [28] }\end{array}$ & $\begin{array}{c}2.4-14.3 \\
\text { years }\end{array}$ & $\begin{array}{l}40 \\
\text { children }\end{array}$ & $\begin{array}{l}\text { CMA: } \\
8 \text { HM reactive } \\
18 \text { HM tolerant } \\
7 \text { outgrown }\end{array}$ & $\begin{array}{l}\text { Allergen- } \\
\text { specific } \\
\text { CD25+CD27+ } \\
\text { T cells } \\
\text { Polyclonal } \\
\text { Treg cells }\end{array}$ & $\begin{array}{l}\uparrow \text { in } \mathrm{PB}^{\mathrm{a}} \\
\mathrm{HM} \text { tolerant } \\
\text { Intermediate in } \\
\text { outgrown } \\
\downarrow \text { in } \mathrm{PB}^{\mathrm{a}} \text { in } \\
\mathrm{HM} \text { reactive } \\
\equiv \text { in } \mathrm{PB}^{\mathrm{a}}\end{array}$ & $\equiv$ & n.a. & $\begin{array}{l}\text { A higher frequency } \\
\text { of milk allergen- } \\
\text { specific Treg cells } \\
\text { correlates with a } \\
\text { phenotype of mild } \\
\text { clinical disease and } \\
\text { favorable prognosis. } \\
\text { Milk allergen-specific } \\
\text { regulatory T cells }{ }^{\mathrm{c}} \text { may } \\
\text { play a role in the } \\
\text { resolution of milk } \\
\text { allergy }\end{array}$ \\
\hline $\begin{array}{l}\text { Sicherer } \\
\text { et al. [29] }\end{array}$ & $\begin{array}{l}3-15 \\
\text { months }\end{array}$ & $\begin{array}{l}308 \\
\text { infant }\end{array}$ & $\begin{array}{l}\text { CMA } \\
\text { Egg allergy }\end{array}$ & n.a. & n.a. & n.a. & $\begin{array}{l}\equiv \text { FOXP3 } \\
\text { expression } \\
\equiv \text { IL10 } \\
\text { expression }\end{array}$ & $\begin{array}{l}\text { Allergen-specific IL4 } \\
\text { expression might be } \\
\text { a marker of allergic risk }\end{array}$ \\
\hline $\begin{array}{l}\text { Westerholm- } \\
\text { Ormio } \\
\text { et al. [42] }\end{array}$ & n.a. & n.a. & FA & n.a. & n.a. & $\downarrow$ & $\begin{array}{l}\downarrow \text { FOXP3 } \\
\text { expression }\end{array}$ & $\begin{array}{l}\text { Foxp3 } 3+\text { cells }^{\mathrm{b}} \text { are } \\
\text { increased in the } \\
\text { duodenum of patients } \\
\text { with untreated FA, } \\
\text { but these cells are not } \\
\text { able to suppress the } \\
\text { harmful immune } \\
\text { response, indicated } \\
\text { by the low expression } \\
\text { of Foxp3 transcripts }\end{array}$ \\
\hline
\end{tabular}

$\downarrow$ decreased frequency, $\uparrow$ increased frequency, $\equiv$ equal frequency, n.a. data not available, $P B$ peripheral blood, $C B$ cord blood, FOXP3 forkhead box P3, Treg T regulatory cells, FA food allergy, $C M A$ cow milk allergy

${ }^{\mathrm{a}}$ Expressed as a percentage relative to total CD4+ T cells

${ }^{\mathrm{b}}$ Unstimulated cells

${ }^{\mathrm{c}}$ Stimulated cells

level of allergen-specific Treg cells and better prognosis [28]. The data of Shreffler et al. suggest that there may be no functional defect of the CD25+ Treg cell subset in individuals with allergy but that a higher frequency of these cells is associated with tolerance. It has been also presented that children with milk allergy who are strictly avoiding the antigen have a low frequency of Tregs [28]. We demonstrated that the FOXP3 gene expression was the highest in 
children who acquired tolerance to foods, lower in heated allergen tolerant children, and the lowest among heated allergen reactive children. Our results, similarly to the studies of Karlsson et al., Mori et al., and at least partly to Sheffler et al. [26, 28, 41], indicate the significance of FOXP3 gene expression in tolerance induction. This indirectly suggests, in compliance with the others, that heated milk or heated egg-tolerant children would be more likely to outgrow FA [29, 48]. It suggests also that mucosal induction of tolerance against dietary antigens is associated with the development of CD4+CD25+ Treg cells. In contrast, Savilahti et al. question the concept that Tregs activation in peripheral blood indicates induction of tolerance in FA [27]. Moreover, Sicherer et al. did not report any evidence of increased regulatory $\mathrm{T}$ cell responses in food allergic and non-allergic groups of children, as measured by the levels of FOXP3 and IL-10 expression [29]. Our results are contrary to the above-mentioned findings but, in line with the study of Westerholm-Ormio et al. who demonstrated the decreased ratio of FOXP3 mRNA to FOXP3 cells in patients with FA. The author reported that FOXP3 cells are increased in the duodenum of patients with untreated FA; however, these cells are not able to suppress the harmful immune response, indicated by the low expression of FOXP3 transcripts [42].

To our knowledge, the relationship between the number of Tregs and FA severity has not been emphasized so far. Our study demonstrated no relationship between FOXP3, IL-10, and TGF- $\beta$ expression and the severity of clinical response after oral food challenge. Opposite to a previous studies, although concerning asthma or atopic dermatitis $[24,49]$, we showed that the lowest, however nonsignificant, level of FOXP3 expression affected children with severe reaction after food challenge, which may indicate primary or predominant defect of nTregs as compared with the possible compensatory increase in $\mathrm{T}$ effector cells in these children. Another explanation of this finding may be associated with a greater defect of Tregs in severe type of disease, or possible recruitment of Tregs into the gastrointestinal tract by the presence of antigen.

Several studies indicate the role of TGF- $\beta$ and IL-10 in oral tolerance $[1,3,12]$. Tiemessen et al. suggested that activated CD4+CD25high $\mathrm{T}$ cells might contribute to the tolerogenic immune response toward an antigen, through the production of IL-10 [1]. Additionally, it was detected that proportions of $\mathrm{T}$ cells of food-sensitized children spontaneously secreting IL-10 were lower than in nonatopic children [10]. It was found that impaired production of IL-10 in the patches of Peyer et al. favored the development of food allergy [13]. The potential role of IL-10 in the resolution of milk (and other) allergy was also indirectly supported by the observation made by many investigators that an elevation of $\mathrm{IgG} 4$ (and ratio of $\mathrm{IgG} 4 /$
$\mathrm{IgE})$ is associated with tolerance and that in vitro IL-10 can modulate $\mathrm{TH} 2$ cytokine-induced B cell class switching in favor of $\operatorname{IgG} 4$ over $\operatorname{IgE}[50,51]$. We have demonstrated significantly lower IL-10 gene expression in children with IgE-dependent FA than in the control group. It is consistent with other studies $[10,13]$. The lack of differences between IL-10 and TGF- $\beta$ expression in our study group and the course of food allergy related to tolerance achievement may suggest that the FOXP3 expression is more significant in tolerance induction as compared to IL10 and TGF- $\beta$ expression. It is difficult to say whether such a result is due to a Treg defect in cytokine secretion or to the methods used in our study. Unfortunately, we have not evaluated the function of definite cells but the total genes expression of these cytokines, and additionally, we determined it at one point of time, in stable conditions, theoretically without any allergen influence. Perhaps the analysis of gene expression carried out at different points of time might indicate some differences.

Our study does not reveal differences in TGF- $\beta$ expression. Beyer et al. showed no expression of TGF- $\beta$ and IL-10 in specific cells of duodenal mucosa in children with gastroenteropathy in the course of CMA [52]. According to recent studies, the role of TGF- $\beta$ remains controversial [14]. Nevertheless, previous studies demonstrated decreased potential for TGF- $\beta$ production in food allergic children $[3$, $11,12]$.

Opposite to Lee et al. [24] and in line with Jartti et al. [22] and Hinz et al. [32], we show significant inverse correlation between the FOXP3 and IIgE level. In addition, Matsumoto et al., using a mouse model, revealed that the frequency of Foxp3+CD4+CD25+ T cells was inversely correlated with BHR and allergen-specific IgE levels in the serum [43].

In our study, all children were on the elimination diet, in a stable condition, and out of season in the case of seasonal allergy, so fundamentally children were not exposed to allergens. Therefore, we suggest that our finding results from a possible inherent defect in suppression.

Our study has some limitations that deserve a comment. First, we studied the FOXP3 expression within the PBMC cell population and only in peripheral blood samples of food allergic patients and non-atopic controls. Certainly an evaluation of FOXP3 expression will be more appropriate within the $\mathrm{CD} 4+\mathrm{CD} 25$ high $\mathrm{T}$ cell population, but since recent studies indicate the presence of FOXP3 in the different cells, it seems that the evaluation only in CD4 $+\mathrm{CD} 25+$, in turn, does not encompass all the cells expressing FOXP3. This is the FOXP3 gene that is the most responsible for regulatory functions that are characteristic not only for CD4+CD25+ T but also for other cells. Secondly, however, as Tregs can differ between the peripheral blood and the site of inflammation, it would be 
interesting to study FOXP3 expression in intestinal biopsies or target organs in food allergic patients. Finally, our study population was rather small and heterogeneous. It is therefore possible that due to low statistical power, some effects could not be reliably detected or excluded. Thus, although some effects concerning FOXP3 expression have been confirmed by the authors, the study cannot provide definite proof on the differences of the control and study groups in regard of FOXP3 and IL10 expression, but it does elucidate the involvement of both factors in the process of food allergy. Another shortcoming of the study is post hoc analysis and to draw definitive conclusions would carry out further research.

Possibility of new therapeutic approaches based on the modulation of Tregs is certainly a hope for the future in the treatment of food allergy. Thus, our findings warrant longitudinal studies to see how the studied values change as patients may outgrow their allergy.

\section{Conclusions}

1. Children with food allergy showed statistically significant lower level of the FOXP3 and IL-10 gene expression than healthy children.

2. Children acquiring tolerance to the food show significantly higher levels of the FOXP3 gene expression than children with active food allergy.

3. The correlation between the level of FOXP3 and total IgE was detected.

Open Access This article is distributed under the terms of the Creative Commons Attribution Noncommercial License which permits any noncommercial use, distribution, and reproduction in any medium, provided the original author(s) and source are credited.

\section{References}

1. Tiemessen MM, Van Ieperen-Van Dijk AG, Bruijnzeel-Koomen CA, Garssen J, Knol EF, Van Hoffen E. Cow's milk-specific Tcell reactivity of children with and without persistent cow's milk allergy: key role for IL-10. J Allergy Clin Immunol. 2004;113:932-9.

2. Sletten GB, Halvorsen R, Egaas E, Halstensen TS. Memory T cell proliferation in cow's milk allergy after CD25+ regulatory $\mathrm{T}$ cell removal suggests a role for casein-specific cellular immunity in IgE-mediated but not in non-IgE-mediated cow's milk allergy. Int Arch Allergy Immunol. 2007;142:190-8.

3. Karlsson MR, Kahu H, Hanson LA, Telemo E, Dahlgren UI. An established immune response against ovalbumin is suppressed by a transferable serum factor produced after ovalbumin feeding: a role of CD25 regulatory cells. Scand J Immunol. 2002;55:470-7.
4. Chatila TA. Role of regulatory $\mathrm{T}$ cells in human diseases. J Allergy Clin Immunol. 2005;116:949-59.

5. Chehade M, Mayer L. Oral tolerance and its relation to food hypersensitivities. J Allergy Clin Immunol. 2005;115:3-12.

6. Akdis M, Blaser K, Akdis CA. T regulatory cells in allergy: novel concepts in the pathogenesis, prevention, and treatment of allergic diseases. J Allergy Clin Immunol. 2005;116:961-8.

7. Baecher-Allan C, Brown JA, Freeman GJ, Hafler DA. CD4 $+\mathrm{CD} 25$ high regulatory cells in human peripheral blood. J Immunol. 2001;167:1245-53.

8. Fowler S, Powrie F. Control of immune pathology by IL-10secreting regulatory $\mathrm{T}$ cells. Springer Semin Immunopathol. 1999;21:287-94.

9. Powrie F, Carlino J, Leach MW, Mauze S, Coffman RL. A critical role for transforming growth factor-beta but not interleukin 4 in the suppression of T helper type 1-mediated colitis by CD45RBlow CD4 + T cells. J Exp Med. 1996;183:2669-74.

10. Scott-Taylor TH, Hourihane JB, Harper J, Strobel S. Patterns of food allergen-specific cytokine production by $\mathrm{T}$ lymphocytes of children with multiple allergies. Clin Exp Allergy. 2005;35:1473-80.

11. Rautava S, Isolauri E. Cow's milk allergy in infants with atopic eczema is associated with aberrant production of interleukin-4 during oral cow's milk challenge. J Pediatr Gastroenterol Nutr. 2004;39:529-35.

12. Perez-Machado MA, Ashwood P, Thomson MA, et al. Reduced transforming growth factor-beta1-producing $\mathrm{T}$ cells in the duodenal mucosa of children with food allergy. Eur J Immunol. 2003;33:2307-15.

13. Frossard CP, Tropia L, Hauser C, Eigenmann PA. Lymphocytes in Peyer patches regulate clinical tolerance in a murine model of food allergy. J Allergy Clin Immunol. 2004;113:958-64.

14. Saurer L, Mueller C. T cell-mediated immunoregulation in the gastrointestinal tract. Allergy. 2009;64:505-19.

15. Liu W, Putnam AL, Xu-Yu Z, Szot GL, Lee MR, Zhu S, et al. CD127 expression inversely correlates with FoxP3 and suppressive function of human CD4+ Treg cells. J Exp Med. 2006;203:1701-11.

16. Sakaguchi S, Ono M, Setoguchi R, Yagi H, Hori S, Fehervari Z, et al. Foxp3 $+\mathrm{CD} 25+\mathrm{CD} 4+$ natural regulatory $\mathrm{T}$ cells in dominant selftolerance and autoimmune disease. Immunol Rev. 2006;212:8-27.

17. Hori S, Nomura T, Sakaguchi S. Control of regulatory T cell development by the transcription factor Foxp3. Science. 2003;299:1057-61.

18. Wan YY, Flavell RA. Regulatory T-cell functions are subverted and converted owing to attenuated Foxp3 expression. Nature. 2007;445:766-70.

19. Gavin MA, Rasmussen JP, Fontenot JD, Vasta V, Manganiello VC, Beavo JA, et al. Foxp3-dependent programme of regulatory T-cell differentiation. Nature. 2007;445:771-5.

20. Xystrakis E, Boswell SE, Hawrylowicz CM. T regulatory cells and the control of allergic disease. Expert Opin Biol Ther. 2006;6:121-33.

21. Ling EM, Smith T, Nguyen XD, Pridgeon C, Dallman M, Arbery $\mathrm{J}$, et al. Relation of CD4+CD25+ regulatory T-cell suppression of allergen driven T-cell activation to atopic status and expression of allergic disease. Lancet. 2004;363:608-15.

22. Jartti T, Burmeister KA, Seroogy CM, Jennens-Clough ML, Tisler CJ, Salazar LP, et al. Association between CD4(+)CD25(high) T cells and atopy in children. J Allergy Clin Immunol. 2007;120:177-83.

23. Provoost S, Maes T, van Durme YM, Gevaert P, Bachert C, Schmidt-Weber CB, et al. Decreased FOXP3 protein expression in patients with asthma. Allergy. 2009;64:1539-46.

24. Lee JH, Yu HH, Wang LC, Yang YH, Lin YT, Chiang BL. The levels of $\mathrm{CD} 4+\mathrm{CD} 25+$ regulatory $\mathrm{T}$ cells in paediatric patients with allergic rhinitis and bronchial asthma. Clin Exp Immunol. 2007;148:53-63. 
25. Verhagen J, Akdis M, Traidl-Hoffmann C, Schmid-Grendelmeier P, Hijnen D, Knol EF, et al. Absence of T-regulatory cell expression and function in atopic dermatitis skin. J Allergy Clin Immunol. 2006;117:176-83.

26. Karlsson MR, Rugtveit J, Brandtzaeg P. Allergen-responsive CD4 $+\mathrm{CD} 25+$ regulatory $\mathrm{T}$ cells in children who have outgrown cow's milk allergy. J Exp Med. 2004;199:1679-88.

27. Savilahti EM, Karinen S, Salo HM, Klemetti P, Saarinen KM, Klemola $\mathrm{T}$, et al. Combined $\mathrm{T}$ regulatory cell and Th2 expression profile identifies children with cow's milk allergy. Clin Immunol. 2010;136:16-20.

28. Shreffler WG, Wanich N, Moloney M, Nowak-Wegrzyn A, Sampson HA. Association of allergen-specific regulatory T cells with the onset of clinical tolerance to milk protein. J Allergy Clin Immunol. 2009;123:43-52.

29. Sicherer SH, Wood RA, Stablein D, Burks AW, Liu AH, Jones $\mathrm{SM}$, et al. Immunologic features of infants with milk or egg allergy enrolled in an observational study (Consortium of Food Allergy Research) of food allergy. J Allergy Clin Immunol. 2010;125:1077-83.

30. Smith M, Tourigny MR, Noakes P, Thornton CA, Tulic MK, Prescott SL. Children with egg allergy have evidence of reduced neonatal CD4(+)CD25(+)CD127(lo/-) regulatory T cell function. J Allergy Clin Immunol. 2008;121:1460-6.

31. Haddeland U, Karstensen AB, Farkas L, Bo KO, Pirhonen J, Karlsson M, et al. Putative regulatory T cells are impaired in cord blood from neonates with hereditary allergy risk. Pediatr Allergy Immunol. 2005;16:104-12.

32. Hinz D, Simon JC, Maier-Simon C, Milkova L, Röder S, Sack U, et al. Reduced maternal regulatory $\mathrm{T}$ cell numbers and increased $\mathrm{T}$ helper type 2 cytokine production are associated with elevated levels of immunoglobulin E in cord blood. Clin Exp Allergy. 2010;40:419-26.

33. Tiemessen MM, Hoffen EV, Knulst AC, Zee JVD, Knol EF, Taams LS. CD4 CD25 regulatory T cells are not functionally impaired in adult patients with IgE-mediated cow's milk allergy. J Allergy Clin Immunol. 2002;110:934-6.

34. Dreborg S, Frew A, et al. Position paper. Allergen standardization and skin tests. The European Academy of Allergology and Clinical Immunology. Allergy. 1993;48:48-82.

35. Bindslev-Jensen C, Ballmer-Weber BK, Bengtsson U, Blanco C, Ebner C, Hourihane J, et al. Standardization of food challenges in patients with immediate reactions to foods - position paper from the European Academy of Allergology and Clinical Immunology. Allergy. 2004;59:690-7.

36. Sampson HA. Anaphylaxis and emergency treatment. Pediatrics. 2003;111:1601-8.

37. Benhamou AH, Zamora SA, Eigenmann PA. Correlation between specific immunoglobulin $E$ levels and the severity of reactions in egg allergic patients. Pediatr Allergy Immunol. 2008;19:173-9.

38. Xiang L, Marshall Jr GD. Immunomodulatory effects of in vitro stress hormones on FoxP3, Th1/Th2 cytokine and costimulatory molecule mRNA expression in human peripheral blood mononuclear cells. Neuroimmunomodulation. 2011;18(1):1-10.

39. Mubeccel A. Immune tolerance in allergy. Curr Opin Immunol. 2009;21:700-7.

40. Yang M, Yang C, Mine Y. Multiple T cell epitope peptides suppress allergic responses in an egg allergy mouse model by the elicitation of forkhead box transcription factor 3- and transforming growth factor-beta-associated mechanisms. Clin Exp Allergy. 2010;40:668-78.

41. Mori F, Bianchi L, Pucci N, Azzari C, De Martino M, Novembre E. CD4+CD25+Foxp3+ T regulatory cells are not involved in oral desensitization. Int J Immunopathol Pharmacol. 2010;23:359-61.

42. Westerholm-Ormio M, Vaarala O, Tiittanen M, Savilahti E. Infiltration of Foxp3- and Toll-like receptor-4-positive cells in the intestines of children with food allergy. J Pediatr Gastroenterol Nutr. 2010;50:367-76.

43. Matsumoto K, Inoue H, Fukuyama S, Kan-O K, Eguchi-Tsuda M, Matsumoto T, et al. Frequency of Foxp3+CD4CD25+ T cells is associated with the phenotypes of allergic asthma. Respirology. 2009;14:187-94.

44. Robinson DS, Larche M, Durham SR. Tregs and allergic disease. J Clin Invest. 2004;114:1389-97.

45. Hartl D, Koller B, Mehlhorn AT, Reinhardt D, Nicolai T, Schendel DJ, et al. Quantitative and functional impairment of pulmonary $\mathrm{CD} 4+\mathrm{CD} 25$ hi regulatory $\mathrm{T}$ cells in pediatric asthma. J Allergy Clin Immunol. 2007;119:1258-66.

46. Ou LS, Goleva E, Hall C, Leung DY. T regulatory cells in atopic dermatitis and subversion of their activity by superantigens. $\mathrm{J}$ Allergy Clin Immunol. 2004;113:756-63.

47. Taylor AL, Hale J, Hales BJ, Dunstan JA, Thomas WR, Prescott SL. FOXP3 mRNA expression at 6 months of age is higher in infants who develop atopic dermatitis, but is not affected by giving probiotics from birth. Pediatr Allergy Immunol. 2007;18:10-9.

48. Nowak-Wegrzyn A, Bloom KA, Sicherer SH, Shreffler WG, Noone S, Wanich N, et al. Tolerance to extensively heated milk in children with cow's milk allergy. J Allergy Clin Immunol. 2008; $122: 342-7$

49. Ito $\mathrm{Y}$, Adachi $\mathrm{Y}$, Makino $\mathrm{T}$, Higashiyama $\mathrm{H}$, Fuchizawa $\mathrm{T}$, Shimizu T, et al. Expansion of FOXP3-positive CD4+CD25+ T cells associated with disease activity in atopic dermatitis. Ann Allergy Asthma Immunol. 2009;103:160-5.

50. Shi HZ, Li S, Xie ZF, Qin XJ, Qin X, Zhong XN. Regulatory CD4 $+\mathrm{CD} 25+\mathrm{T}$ lymphocytes in peripheral blood from patients with atopic asthma. Clin Immunol. 2004;113:172-8.

51. Ruiter B, Knol EF, van Neerven RJ, Garssen J, BruijnzeelKoomen CA, Knulst AC, et al. Maintenance of tolerance to cow's milk in atopic individuals is characterized by high levels of specific immunoglobulin G4. Clin Exp Allergy. 2007;37:1103-10.

52. Beyer K, Castro R, Birnbaum A, et al. Human milk-specific mucosal lymphocytes of the gastrointestinal tract display a $\mathrm{TH} 2$ cytokine profile. J Allergy Clin Immunol. 2002;109:707-13. 